\title{
PEMBERDAYAAN KELOMPOK TANI DI DESA PACCING KECAMATAN PATIMPENG KABUPATEN BONE
}

\author{
${ }^{1}$ Ratnawati, ${ }^{2}$ Mappamiring, ${ }^{3}$ Ansyari Mone \\ 1) Jurusan Ilmu Administrasi Negara Fisipol Unismuh Makassar \\ 2) Jurusan Ilmu Administrasi Negara Fisipol Unismuh Makassar \\ 3) Jurusan Ilmu Administrasi Negara Fisipol Unismuh Makassar
}

\begin{abstract}
The objective of the research is to know how the service empowerment farmers group an the obstacle factors in the empowerment of farmers group in Paccing Village, Bone Regency. The type of the research is descriptive and qualitative which has eleven informants. The data collecting techniques used observation and interview. The data was analyzed using descriptive technique. The research result show that the empowerment of farmers group have not maximal the need of the because the lack capital and maintenance costs while price quite large, there is another factor that became the obstacles of this empowermentis minimal know ledge of farming communities both technology and treatment techniques farming.
\end{abstract}

Keywords: Empowerment, farmer group

\begin{abstract}
ABSTRAK
Adapun tujuan dilakukannya penelitian ini ialah untuk mengetahui bagaimana pemberdayaan kelompok tani dan faktor penghambat dalam pemberdayaan kelompok tani di Desa Paccing Kabupaten Bone. Jenis penelitian adalah deskriptif kualitatif dengan informan sebelas orang. Teknik pengumpulan data dikumpulkan dengan menggunakan instrumen berupa observasi, wawancara, terhadap informan. Data tersebut dianalisis secara deskriptif. Hasil penelitian ini menunjukkan bahwa pemberdayaan kelompok tani belum maksimal karena masih kurangnya modal sementara harga dan biaya perawatan bertani cukup besar. Kemudian faktor penghambat dalam pemberdayaan adalah minimnya pengetahuan masyarakat petani baik itu dalam teknologi maupun teknik perawatan dalam bertani.
\end{abstract}

Kata kunci: Pemberdayaan, Kelompok Tani 


\section{PENDAHULUAN}

Tigkah laku manusia sangat berpengaruh pada terciptanya kemampuan dan keterampilan. Realita menyadarkan bahwa sumber utama untuk meciptakan keberdayaan adalah adanya pengetahuan dan keterampilan yang dimiliki seseorang, baik itu merupakan bagian dari pemerintah maupun bagian dari anggota masyarakat. Kebijakan pemerintah untuk mendorong percepatan penyelesaian masalah petani harus memiliki sinergi yang baik pada kondisi yang aktual yang dimiliki oleh masyarakat petani serta kebijakan khusus mengarah pada persoalan yang dihadapi oleh masyarakat petani.

\section{Program pembangunan} pertanian perlu adanya konsep berkelanjutan. Keberlanjutan di artikan sebagai menjaga agar suatu upaya terus berlangsung kemampuan untuk bertahan dan menjaga agar tidak merosot. Technical Advisory Commitee Of the CGIAR 1988 (dalam Coen 1992:2) menyatakan, pertanian berkelanjutan adalah pengelolaan sumber daya yang berhasil untuk usaha pertanian guna membantu kebutuhan manusia yang berubah sekaligus mempertahankan atau meningkatkan kualitas lingkungan dan melestarikan sumber daya alam. Untuk pembangunan sumber daya alam perlu adanya perencanaan SDM terlebih dahulu . perencanaan pada dasarnya merupakan pengambilan keputusan sekarang untuk hal-hal yang akan di kerjakan di masa depan.

Berelson dan G. Steiner (Donni 2014:49) menyatakan bahwa perencanaan sumber daya manusia merupakan perencanaan yang bertujuan untuk mempertahankan dan meningkatkan kemampuan organisasi dalam mencapai tujuan memlalui strategi pengembangan kontribusi pekerjaannya di masa depan. Dalam perencanaan SDM perlu dilakukan pengembangan pemberdayaan.

Efek negatif yang dapat dilihat dari ketidakberdayaan manusia yaitu dengan semakin maraknya penebangan liar, perambahan kawasan, dan lain-lain yang semakin 
mengakibatkan parahnya kerusakan lahan. Sementara itu keberadaan dan ketergantungan masyarakat lokal terhadap sumber dayaalam angat mempengaruhi keberhasilan pembangunan tanaman pertanian atau pengelolaan lahan.

Menurut $\begin{aligned} & \text { Ndraha } \\ & \text { (2003) } \\ & \text { diperlukan berbagai } \\ & \text { pemberdayaan, } \\ & \text { program } \\ & \text { diantaranya }\end{aligned}$
semberdayaan budaya, dan pemberdayaan
lingkungan. Ndraha (2003) juga
menawarkan berbagai konsep
pemberdayaan masyarakat yang di
kelompokkan dalam beberapa
kegiatan.(1.) Bantuan modal, (2.) Bantuan pengembangan prasarana, (3.) Bantuan pendampingan dan, (4.) Kelembagaan.

Telah ditekankan bahwa untuk pengelolaan sumber daya manusia secara lebih efektif, setiap organisasi mutlak menciptakan suatu sistem informasi sumber daya manusia dalam organisasi.

Menurut Sumodiningrat (1998:177), Pada hakekatnya pemberdayaan berada pada diri manusia sedangkan faktor di luar diri manusia hanyalah berfungsi sebagai stimulus, perangsang munculnya semangat, rasa atau dorongan pada diri manusia untuk memberdayakan dirinya sendiri, untuk mengendalikan dirinya sendiri, untuk mengembangkan dirinya sendiri berdasarkan potensi yang dimilikinya. Jadi memberdayakan masyarakat adalah upaya untuk meningkatkan harkat dan martabat lapisan masyarakat yang dalam kondisi sekarang tidak mampu untuk melepaskan diri dari perangkap kemiskinan dan keterbelakangan, yang merupakan upaya memampukan dan memandirikan masyarakat.

Menurut Kartasasmita (1996 : 144-145), pemberdayaan atau empowerment merupakan suatu konsep pembangunan masyarakat dalam bidang ekonomi dan politik yang bercirikan people centered, participatory, empowering, dan sustainable atau dengan kata lain pemberdayaan yakni upaya membangun daya masyarakat dengan mendorong, memberikan motivasi 
dan membangkitkan kesadaran akan potensi yang dimilikinya serta berupaya untuk mengembangkannya.

Sumber daya manusia merupakan sumber daya terpenting yang dimiliki oleh suatu organisasi, salah satu implikasinya ialah investasi terpenting yang mungkin dilakukan oleh suatu organisasi adalah dibidang sumber daya manusia. Pengembangan SDM merupakan proses pembelajaran jangka panjang dengan menggunakan prosedur yang sistematis dan terorganisasi.

Prijono dkk (1996 : 120) memberikan makna pemberdayaan masyarakat adalah sebagai upaya menjadikan suasana kemanusiaan yang adil dan beradab menjadi semakin efektif secara struktural, baik dalam kehidupan keluarga, masyarakat, negara, regional, internasional maupun dalam bidang politik, ekonomi, psikologi dan lainlain sehingga peran serta pemerintah untuk mencapai kesejahteraan dan kemandirian masyarakat sangat diperlukan dalam setiap kegiatan pemberdayaan masyarakat.
Pemberdayaan tidak sekedar memberikan kewenangan atau kekuasaan kepada pihak yang lemah saja. Dalam pemberdayaan terkandung makna proses pendidikan dalam meningkatkan kualitas individu, kelompok, atau masyarakat sehingga mampu berdaya, memiliki daya saing, serta mampu hidup mandiri.

Pemberdayaan ditujukan untuk mengubah perilaku masyarakat agar mampu berdaya sehingga ia mampu meningkatkan kualitas hidup dan kesejahteraannya. Acuan agen pemberdayaan untuk menentukan perencanaan pemberdayaan yaitu tujuan, materi, metode, alat, evaluasi yang dirumuskan bersama-sama dengan sasaran.

Diera globalisasi saat ini ada dua hal yang menonjol yaitu adanya perkembangan teknologi dan membanjirnya hasil pertanian dari negara lain di pasaran. Hal ini akan sangat menguntungkan bila kita bermain didalamnya dan akan merugikan bila kita hanya menjadi konsumen karena tidak mampu menghadapi konsumen. 
Tujuan pemberdayaan menurut Tjokowinoto dalam Christie S (2005: 16) yang dirumuskan dalam 3 (tiga) bidang yaitu ekonomi, politik, dan sosial budaya. Menurut beliau, kegiatan pemberdayaan masyarakat harus dilakukan secara menyeluruh dan mencakup aspek kehidupan masyarakat dan kelompok masyarakat dari dominasi kekuasan yang meliputi bidang ekonomi, politik, dan sosial budaya.

Konsep pemberdayaan dibidang ekonomi adalah usaha menjadikan ekonomi yang kuat, besar, mandiri, dan berdaya saing tinggi dalam mekanisme pasar yang besar dimana terdapat proses penguatan golongan ekonomi lemah. Sedang pemberdayaan dibidang politik merupakan upaya penguatan rakyat kecil dalam proses pengambilan keputusan yang menyangkut kehidupan berbangsa dan bernegara.

Unsur utama dalam proses pemberdayaan masyarakat adalah pemberian kewenangan dan pengembangan kapasitas masyarakat. Oleh karena itu, apabila masyarakat telah memperoleh kewenanga tetapi belum mempunyai kapasitas untuk menjalankan kewenangan tersebut maka hasilnya juga tidak optimal. Untuk memperoleh kewenangan dan kapasitas dalam mengelola pembangunan, masyarakat perlu diberdayakan melalui proses pemberdayaan atau empowerment.

Konsep pemberdayaan masyarakat di bidang sosial budaya merupakan upaya penguatan rakyat kecil melalui peningkatan, penguatan, dan penegakan nilai-nilai, gagasan, dan norma-norma, serta mendorong terwujudnya organisasi sosial yang mampu memberi kontrol terhadap perlakuan-perlakuan politik dan ekonomi yang jauh dari moralitas.

Menurut Mardikanto dkk (2012 : 199), ada berbagai model pemberdayaan masyarakat dalam dinamika pengembangannya, tidak luput dari peran pemerintah dalam memberdayakan masyarakat. Salah satu cara pemberdayaan masyarakat tani yang paling strategis menurut Sukino (2013:66) adalah melalui kelompok tani, dimana dalam kelompok telah tersusun berdasarkan jenjang kelas kemampuan kelompok 
tani yang terdiri dari dari kelas pemula, kelas lanjut dan kelas utama.

Sedangkan Suharto (dalam Hatu, 2010:103) menjelaskan bahwa dimensi-dimensi yang dapat dijadikan indikator pemberdayaan masyarakat dalam suatu negara disesuaikan dengan program pembangunan yang mengarah pada kesejahteraan masyarakat yaitu;

Masyarakat memenuhi kebutuhan ekonomi, pendidikan dan kesehatan.

(2) Pendapatan masyarakat meningkat dan (3) Masyarakat dapat berpartisipasi dalam pembangunan.

Dalam penelitian ini yang dimaksud dengan pemberdayaan adalah suatu proses yang dilakukan untuk membangun eksistensi peribadi maupun kelompok ke arah yang lebih baik. Sedangkan pemberdayaan kelompok tani merupakan pemberdayaan dilakukan untuk sekumpulan orang-orang tani yang terikat secara informal dalam suatu wilayah yang dipimpin oleh seorang kontak tani. Dan peran utama kelompok tani yaitu sebagai media sosial, sebagai alat untuk mencapai perubahan, dan ebagai motor dalam penggerak perilaku.

Peran utama dalam kelompok tani yaitu sebagai media sosial, sebagai alat untuk mencapai perubahan, dan sebagai motor dalam penggerak. Demikian pula dalam penyebaran dan penerapan inovasi baru, dengan melalui aktivitas kelompok akan lebih cepat dan lebih meluas.

Dalam proses pemberdayaan kelompok tani, dapat meningkatkan kemampuan pengembangan kelompok tani dengan diarahkan penguatan kelompok tani menjadi organisasi kelompok tani yang kuat dan mandiri dengan ciri antara lain:

(1) Adanya pertemuan,

Disusunnya rencana kerja kelompok secara bersama, (3) Memiliki aturan, (4) memiliki pencatatan, Memfasilitasi kegiatan-kegiatan usaha bersama, (6) Seabagai sumber serta pelayanan informasi dan teknologi untuk usaha para petani, (7) Adanya Jalinan kerja sama antara kelompok tani dengan pihak lain, (8) Adanya pemupukan modal usaha baik iuran dari anggota atau penyisihan hasil usaha. 


\section{METODE PENELITIAN}

Jenis data penelitian yang diguanakan dalam penelitian ini adalah kualitatif yaitu prosedur penelitian yang menghasilkan data deskriptif berupa kata-kata tertulis lisan dan perilaku yang diamati.

Jenis tipe penelitian adalah metode deskriptif kualitatif. Dengan informan sebelas orang, teknik pengumpulan data dikumpulkan dengan menggunakan instrumen berupa metode obsevasi, ialah metode mengumpulkan data dengan cara mengamati dan mengadakan komunikasi secara langsung dengan sumber informasi tentang kondisi penelitan .

Wawancara metode yang dilakukan dengan cara melakukan tanya jawabatau percakapan dengan para informan untuk memperoleh data, baik dengan menggunkan daftar pertanyaan ataupun percakapan bebas yang berhubngan dengan permasalahn yang telah dirumuskn sebelumnya. Dan dokumentasi dengan menggunakan dokumentasi demografi desa, dan melihat kondisi wilayah dan berupa catatan-catatan yang berhubungan dengan penelitian.
Sumber data utama dalam penelitian kualitatif ialah kata-kata dan tindakan selebihnya adalah data tambahan dari dokumen dan lain-lain - dimana data hasil penelitian didapatkan melalui dua sumber data, yaitu data sekunder dan data primer. Data tersebut dianalisis secara deskriptif di interpretasi pada informan dengan melakukan wawancara kemudian mengecek kembali data tersebut untuk memahami secara mendalam serta teori-teori yang sesuai dengan data tersebut yang dikumpulkan agar dapat menghasilkan penelitian bermutu.

\section{HASIL DAN PEMBAHASAN}

Istilah pemberdayaan mulai popularitas pada tahun 1990-an dalam istilah pembangunan, kegagalan konsep pembangunan yang menekankan pada aspek makro. Telah di yakini bahwa konsep pemberdayaan sebagai alternatif ampuh untuk penuntusan pembangunan.

Popularitas pemberdayaan ternyata tidak sebanding dengan realisasinya, kegiatan pemberdayaan masyarakat bukan hanya sekedar 
membangun sesuatu, memberikan pelatihan keterampilan, melakukan pendampingan, memberikan sumbangan atau bentuk-bentuk kegiatan lainnya.

Upaya pemerintah untuk meningkatkan nilai tambah dan pendapatan petani telah menetapkan program pengembangan usaha agribisnis. Konsep dalam pemberdayaan mengenai bantuan modal, permasalahan umum yang kerap terjadi di kelompok tani seperti tidak didukung oleh beberapa sistem yang menunjang, tidak didukung oleh aspek teknologi, manajemen, pendanaan yang kurang memadai, serta sebagian besar petani masih memakai cara tradisional.

Kelompok tani di desa Paccing perkebangannya tidak kearah peningkatan pendapatan karena petani secara umum hanya berorientasi pada produksi bukan keuntungan. Usaha tani yang berorientasi pada produksi berarti kurang memperhatikan komuditi yang sesuai mutu/kualitas, kontinuitas, tingkat permintaan serta kurang memperhatikan peluang pasar sehingga hasilnya statis.
Lemahnya institusi permodalan usaha tani yang dijalankan membawa pengaruh yang besar terhadap proses perbaikan dan perkembangan pola usaha tani yang efesien dan efektif.

Daya jangkau terhadap akses pembelian input seperti pupuk, alat dan mekanisme pertanian yang masih kurang membawa dampak terhadap proses usaha tani yang inifisiensi. Salah satu kasusnya pemberian pupuk yang kurang seimbang dikarenakan ketidakmampuan untuk mengadakan jenis pupuk yang dianjurkan.

Dalam upaya membantu kelancaran usaha pertanian yang dilaksanakan di Desa Paccing, saat ini beberapa aspek yang masih menjadi fokus perhatian untuk mendapat penangananseperti aspek ketersediaan saprodi yang harus mendapat ketersediaan yang memadai, sehingga lebih memberikan jaminan keamanan pada saat petani menggunakannya. Diantaranya adalah ketersediaan benih unggul. Pupuk dan saprodi lainnya. Dan juga sarana pengairan yang belum ada. 
Salah satu aspek penting dalam menilai pengembangan sektor pertanian di Desa Paccing diantaranya adalah pengembangan harga. Untuk pengembangan harga jual gabah seringkali keadaan yang terjadi adalah sejauh mana faktor hubungan suplly dan permintaan akan gabah yang terjadi. Sudah menjadi kelaziman bilamana pada saat musim panen harga gabah selalu menurun, dan pada saat musim kering perkembangan harga seringkali melonjak tajam.

Sektor pertanian mendominasi dan menjadi sumber penghidupan yang paling besar di Desa Paccing adalah petani yang berjumlah 610 jiwa, selain itu dari sektor lain walaupun tidak berdominasi tetapi memiliki andil bagi pengembangan dan pembangunan.

$$
\text { Perlindungan dan }
$$

pemberdayaan kelompok tani bisa dilakukan dengan berbagai cara seperti melindungi para kelompok tani dalam bertani seperti kegagalan panen dan resiko harga serta meningkatkan kemandirian dan kedaulatan petani. Selain itu memberikan kepastian usaha tani menyediakan prasarana dan sarana tani, dan menumbuh kembangkan kelembagaan pembiayaan pertanian. Pemberdayaan kelompok tani melalui kelembagaan kelompok tani merupakan salah satu metode pemberdayaan masyarakat yang tepat untuk meningkatkan kualitas hidup masyarakat petani. Lembaga ini merupakan suatu bentuk organisasi kerjasama yang membuat masyarakat mampu mengembangkan responyang sesuai dengan logika yang menjadi suatu wadah yang menyatukan petani secara horisintal.

Penyediaan fasilitas pembiayaan dan permodalan, dunia usaha apapun yang dilakukan modal merupakan peranan yang sangat strategis dimana modal juga dapat menjadi faktor penghambat dalam perkembangan pembangunan pertanian. Dengan penyedian fasilitas dan permodalan diharapkan mampu meningkatkan semangat para petaniuntuk dapat mengembangkan usahanya.

Hal ini dapat dilihat dari salah satu informan mengatakan bahwa terkait dengan pengelolaan pertanian yang selama ini dilakukan masih 
dengan cara-cara yang tradisional ini disebabkan karna keterbatasan ilmu dan pengetahuan mereka terkait sistem kerja yang berbasis tekhnologi, namun mereka menganggap bahwa sistem tradisional ini tidak mengurangi daripada pertanian mereka selama ini.

\section{Perlindungan}

dan pemberdayaan petani adalah kegiatan dalam mengelola sumber daya alam dengan bantuan teknologi dan modal, tenaga kerja, dan untuk menghasilkan pertanian yang mencakup tanaman pangan.dengan adanya masalah modal yang sangat menyulitkan para kelompok tani, mereka sangat mengharapkan adanya bantuan.

Faktor yang menyebabkan sektor pertanian Indonesia lemah yaitu sulitnya akses para petani kesumber modal yang ada. Akses kelompok tani melalui perbankan yang lemah disebabkan karena para kelompok tani tidak memiliki jaminan untuk mendapatkan kredit yang dibutuhkan rumah tangga tani sangat kecil sehingga tidak memenuhi skala kredit di perbankan dan menganggap pertanian adalah usaha yang memiliki resiko tinggi.perjalanan dan perkembangan kelompok tani di Desa Paccing tidak sesuai dengan harapan dan tidak berjalan secara maksimal karena sering ada kasus-kasus nepotisme yang masih marak dikalangan pemerintahan.

Penulis dapat menyimpulkan bahwa modal adalah salah satu kendala utama yang dihadapi para kelompok tani. Dan juga lemahnhya kontrol pemerintah terhadap para petani dan seharusnya untuk menjembatangi kepentingan kelompok dan pihak perbankan perlu adanya lembaga mediator agar kedua pihak tersebut dapat menjalin hubungan kerjasama yang baik.

Pemerintah telah berupaya meningkatkan ketahanan pangan, salah satu faktor yang berperan penting dalam meningkatkan produksi pangan adalah adanya dukungan sarana dan prasarana pertanian. Dukungan prasarana dan sarana pertanian bertujuan untuk meningkatkan produktivitas dan produksi melalui upaya memperluas lahan pertanian, melakukan upaya 
optimasi lahan, meningkatkan persediaan alat dan mesin pertanian, perbaikan distribusi pupuk bersubsidi agar pupuk sampai kepada kelompok tani tidak sesuai dengan yang diharapkan para petani.

Sumberdaya peralatan berupa sarana merupakan salah satu faktor penunjang kelancaran kegiatan pengelolaan usaha tani. Sarana dalam pengelolaan usaha sangat menunjang demi keberhasilan usaha tani yang dikembangkan. Keterbatasan dana berpengaruh terhadap ketersediaan sarana dan prasarana kelompok maupun dalam pengembangan usaha tani.kegiatan dalam pelatihan pengembangan pengetahuan atau sumberdaya kelompok tani sangatlah di dorong oleh adanya sarana dan prasarana. Oleh karena kebutuhan sarana dan prasarana harus diperhatikan dengan seksama guna meningkatkan peningkatan dalam pengembangan hasil produksi.

Pengembangan sistem dan sarana pemasaran hasil pertanian yang dilakukan untuk mengarahkan masyarakat dalam mengembangkan teknik yang digunakan dalam pertanian sehingga dapat meningkatkan hasil pertanian. Sarana pemasaran hasil pertanian maksudnya penyediaan tempat untuk memasarkan hasil pertanian secara lebih luas sehingga memberikan peluang yang lebih besar kepada para petani untuk meningkatkan hasil pertaniaanya.

Jaminan luas lahan pertanian sangat penting bagi para petani dimana lahan yang sempit akan sangat merugikan bagi mereka. Lahan yang sempit akan menyebabkan biaya produksi yang lebih tinggi dari hasil yang dicaapai selesai dapat juga mengakibatkan penggunaan mekanisme pengolahan tanah tidak efektif.

Strategi perlindungan petani juga dilakukan dengan bantuan pendampingan.

Dimana pendampingan merupakan salah satu kemampuan yang perlu dimiliki oleh agen pemberdayaan. Pendampingan yang dilakukan bukan menggurui melainkan sebagai fasilitator, komunikator, dinamisator, dan sebagai pembimbing. Untuk itu peningkatan SDM dan fasilitasi pemerintah dalam teknologi budidaya dan peningkatan nilai 
tambah serta pengembangan pasar sangat diperlukan terutama kegiatan pendampingan.

Kelompok tani sebagai pelaku utama dalam pembangunan pertanian yang perlu diberdayakan agara mampu menganalisa masalah dan peluang yang ada. Pemberdayaan kelompok tani merupakan konsep yang dikembangkan dalam memperkuat kemandirian petani. Kemampuan dan peningkatan kesadaran petani melalui pendampingan, penyuluhan dan pelatihan. Pengembangan usaha jaringan melalui kerjasama, peningkatan pembinaan melalui motivasi, fasilitasi dan bimbingan teknis.

Pendampingan dan penyuluhan suatu hal yang menentukan dalam peningkatan SDM dan peningkatan produksi agar mampu menempatkan dirinya ditengah perubahan dan mampu menjawab permasalahan yang muncul. Dalam proses pendampingan yang dilakukan oleh pemerintah, pemerintah melaksanakan program-program pelatihan untuk meningkatkan produktivitas kelompok tani. Dan penyuluh berperan sebagai penyambung program-program pemerintah daerah agar sampai kepada petani dan mendampingi petani dalam meningkatkan kualitas petani.

Pendampingan perlu memiliki kemampuan dalam meningkatkan kemampuan dasar yang diperlukan oleh para kelompok tani maupun anggotanya. Misalnya dalam mengidentifikasi masalah, memecahkan masalah, mengambil keputusan. Pendampingan dalam pemberdayaan dituntut memiliki kemampuan dalam melakukan interaksi atau membangun hubungan dengan setiap kelompok tani maupun anggotanya.

Pendamipangan dan penyuluhan dimana penyuluh pertanian adalah proses kapasitasi SDM petani melalui sistem pendidikan nonformal, sedangkan pendampingan berarti petani tidak dibiarkan sendirian dalam mengakses informasi, menganalisa situasi yang sedang merekahadapi sehingga akan membuka dan menguatkan SDM petani untk berkarya dalam pembanguan pertanian. 
Pendidikan dengan pelatihan merupakan suatu rangkaian yang tak dapat dipisahkan dalam sistem pengembangan SDM, yang didalamnya terjadi proses perencanaan, penempatan, dan pengembangan tenaga manusia. Antara pendidikan dan pelatihan sulit untuk menarik batasan yang tegas karena baik pendidikan dan pelatihan umum merupakan suatu proses kegiatan pembelajaran yang mentransfer pengetahuan dan keterampilan dari sumber-sumber penerima.

Pemerintah dalam melakukan pendampingan yaitu dengan melakukan pendidikan dan penyuluhan serta memberikan motivasi kepda para kelompok tani Agar para kelompok tani mampu mengolah lahan yang ada dan memanfaatkan dan mengembangkan teknologi dalam pengelolaan sumber daya alam dengan baik.

Sasaran utama dalam pendampingan adalah bagaimana sistem penyuluhan dan pendidikan membuka wawasan kelompok tani yang semula dengan sistem usaha tani produksi menjadi sistem usaha agribisnis yang berorientasi keuntungan penyuluh harus melakukan pembinaan dan meningkatkan kemampuan kelompok tani serta keterampilan dalam mengakses sarana produksi, teknologi, pasca panen, pasar, permodalan sehingga para kelompok tani menjadi kelompok tani yang mandiri.

$$
\text { Penekanan dan pelatihan }
$$
adalah untuk peningkatan kemampuan melaksanakan tugas sekarang, sedangkan pengembangan meningkatkan kemampuan melakukan tugas baru dimasa depan. Akan tetapi karena keterkaitan antra keduanya sangat erat. Perbedaan aksentuasi tersebut bukanlah hal yang perlu ditonjolkan meskipun perlu mendapat perhatian. Dengan cara lain pelatihan adalah suatu bentuk investasi jangka pendek, sedangkan pengembangan merupakan investasi untuk sumber daya manusia jangka panjang. Oleh itu bantuan pendampingan perlu dan penting karena tugas utama dalam pendampingan adalah memfasilitasi proses belajar atau refleksi dan menjadi mediator masyarakat. 
Indikator keberhasilan utama dalam pemberdayaan kelompok tani adalah adanya partisipasi yang tinggi dari masyarakat tani. Salah satu upaya dalam menciptakan partisipasi masyarakat petani yang tinggi diupayakan tumbuh kembangnya suatu organisasi atau membentuk kelembagaan kelompok tani yang ada pada suatu wadah tersebut mempererat kerjasama dalam pertanian.

Fungsi utama kelompok tani menurut undang-undang no 19 tahun 2013 tentang perlindungan dan pemberdayaan petani diantaranya meningkatkan kemampuan anggota kelompok tani dalam mengembangkan usaha tani, memperjuangkan kepentingan anggota dalam mengembangkan kemitraan usaha, menampung dan menyalurkan aspirasi anggota atau kelompok dan membantu menyelesaikan permasalahan anggota dalam berusaha tani.

Penguatan kelembagaan petani diharapkan memiliki organisasi kepengurusan yang aktif. Memiliki unit usaha distribusi, pemasaran atau pengelolahan yang masih berjalan serta dikelola kelompok tani, dan mempunyai SDM yang secara potensial mampu menjalankan usaha tani secara bisnis.

Dilihat dari jumlah kelompok tani yang ada di desa Paccing belum sepenuhnya berjalan dengan baik. Karena sebagian kelompok tani hanya bertindak ketika ada desakan dan bantuan dari pihak pemerintah dan apabila bantuan yang mereka dapat sudah ada sebagian dari anggota kelompok tani tersebut kembali vakum.

Dalam pemberdayaan kelompok tani sarana produksi sebagai faktor pendukung dalam melakukan pemberdayaan. Sarana produksi merupakan pemberian prasarana dan sarana berupa alat pertanian dari pemerintah kepada pemerintah desa sebagai bentuk apresiasi pemerintah daerah untuk melaksanakan program-program pemerintahan. Bentuk dukungan dari pemerintah kepada kelompok tani dalam pemberdayaan kelompok tani di Desa Paccing termasuk pendampingan seperti memberikan pendidikan dan penyuluhan. Pemberian pendidikan dan 
penyuluhan ini dianggap telah terlaksana karena para kelompok tani merasa terbantu dengan adanya pendampingan. Sehingga para kelompok tani mampu meningkatkan hasil produksi tanamannya.

\section{Kompetensi}

agen

pemberdayaan dalam menumbuhkan kemampuan dan menguatkan kelembagaan petani. Untuk meningkatkan kualitas kehidupan dan kesejahteraannyaserta membangun kerjasama antar kelompok atau dalam lembaga dengan saling memahami, menghargai, dan saling menguntungkan.

\section{Pemerintah}

menyediakan wadah kepada masyarakat petani dalam pendampingan untuk mengelola tanaman petani seperti Balai Penyuluhan Kecamatan sebagai tempat pengaduan dan posko penyuluh. Dimulai dengan kelompok tani sebagai penyambung lidah masyarakat tani apabila ada keluhankeluhan.

Dalam pemberdayaan kelompok tani faktor penghambat adalah minimnya sumberdaya pengetahuan yang dimiliki oleh para kelompok tani. Ini membuktikan bahwa sumber daya pengetahuan kelompok tani, sehingga para kelompok tani kurang memperhatikan perkembangan teknologi sehingga cara bertanam masih dengan cara yang lama dan hasilnya juga tdak mengalami peningkatan. Dalam aplikasi pelaksanaan usaha tani hanya berdasarkan kepada pengalaman.

$\begin{array}{rrrr}\text { Rendahnya } & \text { sumber daya } \\ \text { manusia yang } & \text { dimiliki } & \text { oleh }\end{array}$
kelompok tani sangat susah untuk diarahkan. Kelompok tani belum sadar terhadap peningkatan produksi, mereka hanya tau tanam, petik, dan jual. Mereka tidak berpikir tentang keuntungan dari hasil produksi.

\section{KESIMPULAN}

Berdasarkan uraian pembahasan hasil penelitian tentang pemberdayaan kelompok tani di Desa Paccing Kecamatan Patimpeng Kabupaten Bone. Maka penulis dapat mengambil kesimpulan bahwa dalam pemberdayaan dibentuk penguatan kelembagaan tani dengan tujuan dapat menampung keluhan-keluhan 
yang di hadapi masyarakat petani maupun keluhan dari anggota kelompok itu sendiri.

Selain itu, ada pemberdayaan dalam bentuk memberikan prasarana dan sarana kepada kelompok tani Desa Paccing, serta memberikan pendampingan dengan cara memberikan pelatihan dan penyuluhan kepada para kelompok tani agar mereka lebih tau bagaimana caranya merawat tanaman dengan baik, dan bukan lagi tau tentang tanam, petik, jual. Namun dengan pendampingan mereka lebih tau bahwa bertani itu harus mengelolah tanaman dengan baik agar hasilnya pun baik serta perencanaan menyediakan modal dalam mengembangkan usaha tani belum terealisasikan.

Pemberdayaan kelompok tani di pengaruhi dua faktor, faktor yang pertama adalah adanya sarana pendukung berupa alat pertanian yang dapat memudahkan para kelompok tanidalam bertani, serta penguatan kelembagaan ini di lakukan agar hubungan kerja sama antar kelompok tani dengan dinas pertanian dapat terjalin hubungan kerja sama dengan baik, dan juga para anggota kelompok tani maupun ketuanya bisa saling menghargai. Sedangkan faktor keduaadalah minimnya pengetahuan yang dimiliki para kelompok tani terutama dalam bidang teknologi.

\section{DAFTAR PUSTAKA}

Coen. 1992. Pertanian Masa Depan (Pengantar Untuk Pertanian Berkelanjutan Dengan Input Luar Rendah). Yokyakarta; Pt Kanisius

Donni. 2014. Pemberdayan dan Pendampingan Sosial Masyarakat. Gorontolo: Jurnal Inovasi

Hatu. 2010. Perencanaan dan Pendampingan Sosial Masyarakat. Gorontalo: Jurnal Inovasi

Kartasasmita. 1996. Pembangunan untuk Rakyat. Jakarta: Pustaka Cidesindo

Mardikanto, dkk. 2012. Pemberdayaan Masyarakat dalam Perspektif Kebijakan Politik. Bandung: Alfabeta

Ndraha. 2003. Pembangunan Masyarakat: Mempersiapkan Masyarakat Tinggal Landas. Jakarta: Bina Aksara 
Prijono, A,M,W, Pranarka. 1996.

Permberdayaan Konsep,

Kebijakan dan Implementasi.

Jakarta: CSIS

Sumodiningrat. 1998. Membangun

Perekonomian Rakyat.

Yokyakarta: Pustaka Pelajar

Sukino. 2013. Membangun

Pertanian dengan

Pemberdayaan Masyarakat

Tani Terobosan

Menanggulangi Kemiskinan.

Yokyakarta: Pustaka Baru

Press

Tjokowinoto. 2005. Pembangunan

Dilema dan tantangan.

Yokyakarta: Pustaka Belajar 